\title{
Pankreasın kistik neoplazilerinde endoskopik ultrasonografi
}

\author{
Endoscopic ultrasound for the evaluation of cystic neoplasia of the pancreas
}

Mehmet BEKTAŞ

Ankara Üniversitesi Tıp Fakültesi Gastroenteroloji Bilim Dall, Ankara

Pankreas kistlerinin gerçek prevalansı bilinmemekle birlikte büyük hacimli genel popülasyonun incelenmesi çalışmalarında yaklaşık \%1 olarak rapor edilmiștir. Bilgisayarlı tomografi ve manyetik rezonans gibi görüntüleme yöntemlerinin son zamanlarda yaygın kullanımıla pankreas kistlerinin tanısinda artıs vardır. Pankreasın kistik lezyonlarr; psödokist, konjenital kistler ve seröz kist adenom, müsinöz kist adenom, müsinöz kist adenokanser ve intraduktal papiller müsinöz neoplazi gibi neoplastik kistlerinden oluşur. Endoskopik ultrasonografi pankreas kistlerinin morfolojik detayı hakkında es zamanlı yüksek çözünürlüklü bilgi sağlar. Endoskopik ultrasonografiye ince iğne aspirasyonu sitolojisinin eklenmesiyle kistlerin tanısal doğruluğu artar.

Anahtar kelimeler: Endoskopik ultrasonografi, pankreas kistleri
Although the exact prevalence of cystic pancreatic lesions is unknown, it is estimated to be around $1 \%$ of the general population based on large-scale observational imaging studies. Cystic pancreatic lesions are increasingly diagnosed due to the widespread use of cross-sectional imaging modalities like computed tomography and magnetic resonance imaging. Cystic lesions of the pancreas consist of pseudocysts, congenital cysts (sometimes called simple cysts) and cystic neoplasms, including serous cystadenomas, mucinous cystadenomas and cystadenocarcinomas, and intraductal papillary mucinous neoplasms. Endoscopic ultrasound provides real-time high-resolution images of cystic pancreatic lesions with morphological details. The combination of fine-needle aspiration cytology with the other recently available diagnostic markers has further increased its diagnostic accuracy.

Key words: Endoscopic ultrasonography, pancreatic cysts

Histopatolojik değerlendirmelerin sonucuna göre yapılan epidemiyolojik çalışmalarda \%32-39 seröz kistik neoplazi, \%1045 müsinöz kistik neoplazi, \%21-33 intraduktal papiller müsinöz neoplazm (IPMN), \%10 solid pseudo papiller kist, \%10 kistik endokrin neoplazi, \%1 duktal adenokansere bağlı kistik dejenerasyona rastlanmaktadır (2). Günümüzde görüntüleme yöntemlerinin yoğun kullanımına bağlı tesadüfen saptanan asemptomatik pankreas kisti oranları artmıștır. Yapılan çalışmalarda bunların yaklaşı \%60'ının müsin salglayan tümörler [müsinöz kistik neoplazm (MKN) ve (IPMN)], \%30' unun benign siniflandırlamayan kistler (epitelyal kökenli, retansiyon kistleri vb), \%5'inin seröz kist, \%2'sinin kistik pankreatik endokrin tümör ve \%3'ünün ise psödokist olduğu vurgulanmaktadır (10).

Pankreasin kistik neoplazilerinin tanısında abdominal USG, BT/multidedektör BT, manyetik rezonans görüntüleme (MRI), endoskopik retrograd kolanjiopankreatografi (ERCP) (özellikle IPMN tanısında), endoskopik ultrasonografi (EUS), endoskopik ultrasonografi eşliğinde iğne aspirasyon biyopsisi (EUS-FNA) ve EUS-FNA+ fırça yöntemleri kullanılmaktadır (11-12). Pankreas kistleri lokularite, boyut ve pankreas kanalıyla ilişkili olup olmamasına göre de radyolojik olarak sınıflandırılırlar. Lokülaritelerine göre uniloküler, düzgün kenarlı, bilokülllere-lobule kontürlü- kalın septalı, oligo loküler Tablo l'de özetlenmiștir. 


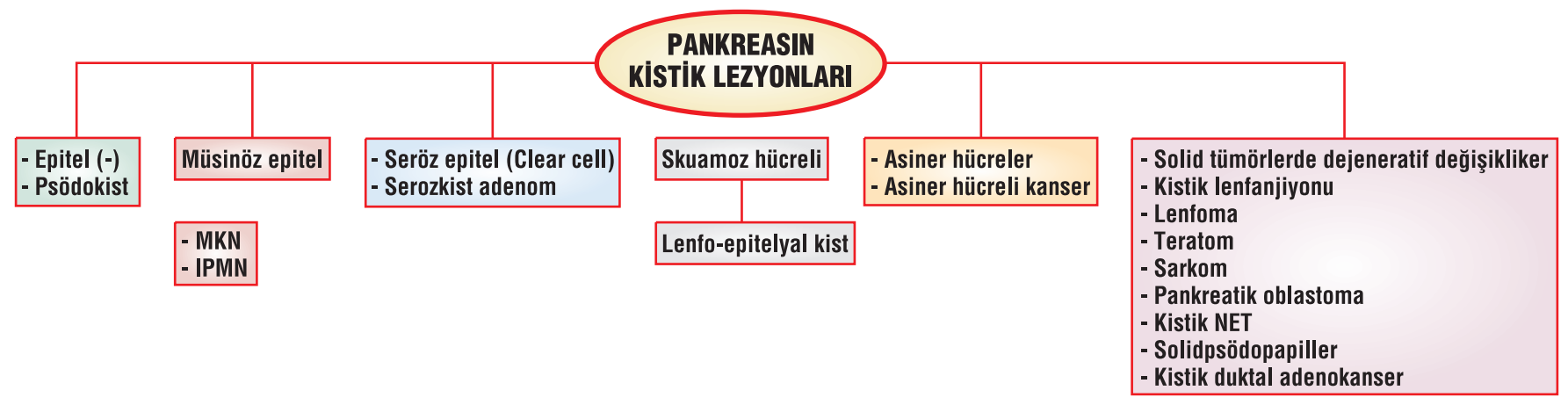

Şekil 1. Histopatolojik değerlendirmeler sonucu kistin içini döşeyen epitel tabakasına göre sınıflandırma

\begin{tabular}{|c|c|c|c|c|c|}
\hline & Seröz kist adenom & Müsinöz kistik neoplazi & Ana kanal IPMN & Yan dal IPMN & SPPN \\
\hline Görülme yaşı & 5-7. dekad & 4-6. dekad & 5-7. dekad & 5-7. dekad & 2-3. dekad \\
\hline Cinsiyet & $\mathrm{K}>\mathrm{E}$ & $K>E$ & $\mathrm{~K}=\mathrm{E}$ & $\mathrm{K}=\mathrm{E}$ & $\mathrm{K}>\mathrm{E}$ \\
\hline Klinik & $\begin{array}{l}\text { Asemptomatik } \\
\text { Karın ağrısı } \\
\text { Kitle etkisi }\end{array}$ & $\begin{array}{l}\text { Asemptomatik } \\
\text { Karın ağrısı } \\
\text { Malignite ile ilgili } \\
\text { semptomlar }\end{array}$ & $\begin{array}{l}\text { Asemptomatik } \\
\text { Karın ağrısı } \\
\text { Pankreatit } \\
\text { Pankreas yetmezliği } \\
\text { Malignite ile ilişkili } \\
\text { semptomlar }\end{array}$ & $\begin{array}{l}\text { Asemptomatik } \\
\text { Pankreatit } \\
\text { Malignite ile ilişkili } \\
\text { semptomlar }\end{array}$ & $\begin{array}{l}\text { Asemptomatik } \\
\text { Karın ağrısı } \\
\text { Kitle etkisi }\end{array}$ \\
\hline EUS bulguları & $\begin{array}{l}\text { Mikrokistik, } \\
\text { Bal peteği görünümü } \\
\text { Oligokistik görünüm }\end{array}$ & $\begin{array}{l}\text { Uniloküler, } \\
\text { Septall, } \\
\text { Duvarında kalsifikasyion, }\end{array}$ & $\begin{array}{l}\text { Ana pankreatik kanal dilate, } \\
\text { Parankimal atrofi, } \\
\text { Solid komponent }\end{array}$ & $\begin{array}{l}\text { Yan dallarda } \\
\text { dilatasyon, } \\
\text { Solid komponent }\end{array}$ & $\begin{array}{l}\text { Solid ve kistik } \\
\text { görünüm, } \\
\text { Kalsifikasyon }\end{array}$ \\
\hline Kist sıvisı & $\begin{array}{l}\text { Ince akışkan, } \\
\text { kanlı olabilir }\end{array}$ & Visköz & Visköz & Visköz & Kanlı \\
\hline Sitoloji & $\begin{array}{l}\text { Glukojen boyanma }(+) \\
\text { Kuboidal hücreler } \\
\text { Atipi (-) }\end{array}$ & $\begin{array}{l}\text { Müsin boyası (+) } \\
\text { Kolumnar hücreler } \\
\text { Değissken atipi, } \\
\text { Solid komponentte } \\
\text { malignite oranı yüksek }\end{array}$ & $\begin{array}{l}\text { Müsin boyası (+) } \\
\text { Kolumnar hücreler } \\
\text { Değisken atipi, } \\
\text { Solid komponentte } \\
\text { malignite oranı yüksek }\end{array}$ & $\begin{array}{l}\text { Müsin boyası (+) } \\
\text { Kolumnar hücreler } \\
\text { Değişken atipi, } \\
\text { Solid komponentte } \\
\text { malignite oranı yüksek }\end{array}$ & $\begin{array}{l}\text { Miksoid stroma } \\
\text { Dallı görünüm, } \\
\text { Solid komponentte } \\
\text { malignite oranı } \\
\text { yüksek }\end{array}$ \\
\hline CEA düzeyi & $<5-20 \mathrm{ng} / \mathrm{ml}$ & $>200 \mathrm{ng} / \mathrm{ml}$ & $>200 \mathrm{ng} / \mathrm{ml}$ & $>200 \mathrm{ng} / \mathrm{ml}$ & $?$ \\
\hline Malignite potansiyeli & Çok düşük & Orta & Yüksek & Düşük-orta & Orta-Yüksek \\
\hline Tedavi & $\begin{array}{l}\text { Semptomatik ise } \\
\text { rezeksiyon }\end{array}$ & Rezeksiyon & $\begin{array}{l}\text { Rezeksiyon ve } \\
\text { sonrasında takip }\end{array}$ & $\begin{array}{l}\text { Yakın takip } \\
\text { Rezeksiyon ve sonrası } \\
\text { takip }\end{array}$ & Rezeksiyon \\
\hline
\end{tabular}

IPMN: Intradüktal papiller müsinöz neoplazm. CEA: Karsinoembriyonik antijen

(<6) ve multi loküler; boyutlarına göre ise multipl mikrokistik, makrokistik-içinde mural nodül olan, bal peteği görünümü, miks (mikrokistik ve makrokistik); pankreas kanalı ile bağlantısına göre de ana kanal ile bağlantılı, yan dal genişlemesi ve kanalla bağlantısız diye gruplandırılırlar (13-16).

BT pankreasın kistik neoplazilerinin tanısında yaygın olarak kullanılan bir yöntemdir; ancak benign malign ayrımını yapmada yetersizdir. Yanlış yorumlanma oranı çok yüksek olup yapılan bir çalışmada seröz ve müsinöz kistlerin \%40'ı psödokist gibi yorumlanmıştır. Tanısal doğruluk oranı da çok değişken olup \%20-95 arasındadır (2, 17-19). Günümüzde kullanımı artan multidedektör BT'nin standart BT'ye üstün olduğu vurgulanmaktadır. Pankreasın neoplastik kistlerinin tanısında kullanılan bir başka yöntemde MRI'dır. MRI BT'den üs- tün olmakla birlikte kist duvarındaki kalsifikasyonları ve septal yapıları göstermede yetersizdir $(20,21)$.

\section{Endoskopik Ultrasonografi}

Günümüzde pankreasın neoplastik kistlerinin tanısında EUS yaygın olarak kullanılır ve tanısal doğruluk oranları BT ve MRI'dan üstündür. EUS işlemi sırasında kist duvarının kalın olması, septalı görünüm, kist içinde mural nodul ve kist duvarında kalsifikasyon varlığı kistin malign olabileceğini düşündürür (6). Seröz kistlerin EUS görünümü genellikle mikrokistik, bal peteği görünümünde, oligokistik ve santral kalsifikasyon şeklindedir. Müsinöz kistik neoplaziler ise uniloküler, septalı, solid komponent ve duvarında kalsifikasyon gözlenir. Ana kanal tutulumlu IPMN'de ise pankreatik kanalda dilatas- 
yon, parankimal atrofi ve bazen solid komponent vardır. Pankreasın kistik neoplazilerinin benign -malign ayrımında EUS'un tanısal doğruluk oranı çok değişkendir. Bir çalışmada Brugge ve arkadaşları 112 vakalık seride EUS'un müsinöznon müsinöz kist ayrımını göstermede tanısal doğruluk oranını \%51 olarak bildirmişlerdir (22). Başka bir çalışmada ise Koito ve arkadaşları 52 hastalık bir seride EUS sonuçlarıyla rezeksiyon materyallerinin histopatolojik sonuçlarını karşılaştırmışlar ve neoplastik-non neoplastik kist ayrımını göstermede EUS'un tanısal doğruluk oranını \%92-96 bulmuşlardır (14). Sonuçların literatürde bu kadar değişik bildirilmesi üzerine yapılan başka bir çalışmada histopatolojik tanısı olan 31 pankreas kist hastasının EUS video görüntüleri tecrübeli endosonografistlerce kör olarak değerlendirilmiştir. Endosonografistlerin solid komponentin ve seröz kist adenomların değerlendirilmesinde orta derecede hem fikir olduğu; buna karşın pankreas kanalı anormalliklerini, septasyonu değerlendirmede ve neoplastik-nonneoplastik lezyonların ayrımında hem fikirlilikte yetersiz oldukları görülmüştür. Sonuç olarak EUS'un morfolojik görünümü, kistik lezyonların malign potansiyel taşıyıp taşımadığını ayırt etmede yetersiz olduğu yorumu yapılmıştır (14).

\section{Endoskopik Ultrasonografi Eşliğinde İnce İğne Aspirasyonu (EUS-FNA)}

Pankreasın neoplastik kistlerinin tanısında EUS'a ince iğne aspirasyonunun ilave edilmesi malign-benign kist ayrımı oranını artırır. Bunun için lineer EUS cihazları kullanılır. Işlem sırasında dikkat edilmesi gereken bazı kurallar vardır. Bunlar: işlemin rahat yapılabilmesi için orta derecede veya derin sedasyon uygulanması, renkli doplerle damarsal yapıların dışlanması, işlem öncesi intravenöz antibiyotik verilmesi ve oral yolla 3-5 gün devam edilmesi, mümkünse kist içine bir kez girilmeli, kist başarılabilirse tamamen aspire edilmeli, kistte nodül veya duvar kalınlığı varsa sıvının aspirasyonu sonrası buralara puncture yapılmalısıdır. Işlem sırasında genellikle 22 Gy iğne kullanılır. Müsin içeriği yüksek olan bazı kistlerde kistin tamamını aspire etmek için bazen 19 Gy iğneler de kullanılabilir (23). Alınan kist sıvisının makroskobik görünümüne ve viskozitesine bakılmalıdır. Alınan kist sıvı örneğinde amilaz, tümör markırları [karsinoembriyonik antijen (CEA), Ca 19/9)] ve sitoloji mutlaka çalışılmalıdır. Eğer kist sıvısı çok yetersiz ise sadece sitilojik inceleme için kullanılmalıdır. Son yllarda özellikle müsinöz karakter dışlanamayan ve cerrahi endikasyonu sınırda olan vakaların ayrımında DNA analizi önerilir. Kist sıvısı psödokistte kahverengi, seröz kist ve basit kistlerde berrak, müsinöz kistlerde ise sarımtırak renktedir. Primer tümörün kistik dejenerasyona bağlı kistler ve nöroendokrin tümörlerde kanlı görünüm olabilir. Sıvının viskozitesine bakıldığında seröz kist ve psödokistlerde viskozite düşük; buna karşın MKN ve IPMN gibi müsinöz kistlerde viskozite yüksektir.
Amilaz: Biyokimyasal incelemelerde kist sıvısında amilaz düzeyine bakılması da oldukça önemlidir. Psödokist ve ana kanal IPMN'de amilaz düzeyi yüksektir. Kist amilaz düzeyi $<250$ eşik değer alındığında seröz kist, müsinöz kistik neoplazi ve müsinöz kistik adenokanseri ayırt etmede sensitivite: $\% 44$, spesifite ise \%98 bildirilmiştir (24). Bu çalışmada psödokist için kist sıvısı amilaz düzeyi ortalama değeri 11000 , IPMN için ise 8000 belirtilmiştir.

Tümör markırları: Literatüre bakıldığında kist sıvısinda CEA, Ca 19/9, Ca 125, Ca72.4 vb. gibi bir çok markır çalışılmıştır. Ancak bugün için etkinliği kanıtlanan en önemli markır CEA'dır. CEA için eşik değer $192 \mathrm{ng} / \mathrm{ml}$ alındığında müsinöz kistleri diğer kistlerden ayırt etmede sensitivite $\% 73$, spesifite ise \%84'dür. Kist sıvısında CEA'nın eşik değeri < $<$ ng/ml alındığında ise diğer kistleri müsinöz kistlerden ayırt etmede sensitivite ve spesifitesi sırasıyla \%100 ve \%86 saptanmıştır (23 25,26). CEA'dan sonra en fazla çalışılan markırlardan biri Ca 19/9'dur. Bazı çalışmalar bunun müsinöz kistleri diğer kistlerden ayırt etmede doğruluk oranının yüksek olduğunu rapor etmiştir. Ancak rutinde kullanımını öneren çok az yayın vardir.

Sitolojik değerlendirme: Sitolojik inceleme için alınan kist s1visı lamlara yayılmalı, bir kısmı havada kurutulurken, diğer kısmı alkolde fikse edildikten sonra incelenmelidir. Sıvının kalan kısmı ise hücre bloğu için kullanılmalı ve immünohistokimyasal incelemeye imkan sağlanmalıdır. Sitopatolojik değerlendirmede seröz kistlerde kuboid hücreler görülür, bunlarda glukojen boyası pozitif olup atipi izlenmez. MKN ve IPMN'de inceleme sırasında kolumnar hücreler görülür, müsin boyası pozitiftir, değişken oranlarda atipid gözlenir ve solid komponentte malignite oranı yüksektir. Solid psödopapiller neoplazide ise miksoid stroma ve dallı görünüm izlenir. EUS-FNA sitolojinin pankreasın neoplastik kistik lezyonlarında tanısal doğruluğu \%55-97 arasında değişir $(23,27)$. Retrospektif olarak gerçekleştirdiğimiz bir çalışmamızda 20062009 arası pankreas kisti saptanan 191 olgunun verileri değerlendirildi. EUS-FNA yapılan 172 olgunun sitopatolojik incelemesinde \%37.2 benign epitel, \%26.7 müsinöz neoplazi, \%12.8 adenokanser, \%7 nöroendokrin tümör, \%5.2 IPMN, \%3.5 psödokist, \%2.9 seröz kist, \%2.9 yetersiz materiyal, \%1.2 solid psödopapiller neoplazm (SPPN) ve \%0.6 metastaz saptandı (27). Aynı dönemde pankreatik EUS-FNA ile nöroendokrin tümör tanısı konulan tüm hastaların sayısı 52 idi. Bunların 40 tanesi solid, 12 tanesi kistik karakterdeydi. Tüm pankreatik nöroendokrin tümörler içinde kistik pankreatik nöroendokrin tümör oranı \%23.1 bulundu (28).

Pankreasin kistik neoplazilerinden özellikle IPMN'in diğer organ maligniteleriyle yakın ilişkisi gösterilmiştir. Yapılan bir çalışmada 42 IPMN olgusuyla 46 duktal adenokanser olgusunda pankreas dışı maligniteler araştırılmış ve IPMN'li hasta grubunda over all neoplazi oranı \%48 (20/42), cerrahi öncesi 
veya cerrahi sırasında \%33 (14/42) ve cerrahi sonrası takiplerde ise \%24 (10/42) saptanmıştır. Buna karşın duktal adenokanser grubunda over all, cerrahi sirasında ve cerrahi sonrasında pankreas dışı malignite oranı sırasıyla \%11 (5/46), \%9 (4/46) ve \%2 (1/46) saptanmıştır. $(\mathrm{p}<0.001, \mathrm{p}<0.01, \mathrm{p}<0.01)$ (29). Pankreasın kistik lezyonlarının pankreas dışı organ kistleriyle ilişkisi otozomal dominant böbrek kisti hastalarında mevcuttur. Biz yaptığımız bir çalışmada EUS ile pankreas kisti saptanan 191 hastanın BT veya MRI görüntülerini retrospektif olarak taradık ve pankreas dışı organ kisti oranlarına baktık. Kontrol grubu ise yaş, cinsiyet ve sayı olarak aynı EUS incelemesinde pankreası normal olan veya pankreasında solid lezyon saptanan hastalardan oluşturuldu. Pankreas kisti olan olguların \%50.8'inde her hangi bir organda pankreas dışı kist, \%31.9 karaciğer kisti, \%29.8 böbrek kisti ve \%3.7 dalak+over kisti saptandı. Kontrol grubunda ise tüm kist, karaciğer kisti, böbrek kisti ve dalak+over kisti oranları sirasıyla \%34.6, $\% 15.7, \% 20.4$ ve \%1.6 saptand ( $\mathrm{p}=0.001, \mathrm{p}=0.02$, $\mathrm{p}=0.04$ ve $\mathrm{p}=0.34$ ). Sitoloji sonuçlarıyla diğer organ kistlerinin ilişkisi araştırıldığında her hangi bir ilişki gözlenmedi (28).

Psödokist ile kistik tümöral lezyonların ayırımı oldukça önemlidir. Psödokist hastalarında pankreatit veya travma öyküsü vardır. Bunlar morfolojik incelemede genellikle tek, nonloküle, septa içermeyen, duvar kalınğı $4 \mathrm{~mm}$ altında, \%65'den fazla pankreatik kanalla bağlantılıdır. Aspirasyon sıvısının incelmesinde viskozitesi düşük, amilaz düzeyi yüksek, sitopatolojik incelemede fibrotik değişiklikler ve inflamatuvar hücreler gözlenir. Kistik tümöral yapılarda ise pankreatit hikayesi genellikle yoktur. Morfolojik olarak multiloküle, kalın duvarlı ve genellikle pankreatik kanalla ilişkisizdir. Kist sıvısının viskozitesi yüksektir ve sitopatolojik incelemede malign veya premalign hücreler gözlenir (9).

DNA analizi: Bir kısım hastalarda kistlerin malign-benign ayrımında zorluk yaşanmaktadır. Bu nedenle kist sıvısından mutasyon analizi ve DNA ölçümlerinin yapılması gündemdedir. Seröz kist adenomlarda 3. kromozomun uzun kolunda mutasyon varken; IPMN'de p53 ve p16'da heterozigodite kaybi; MKN ve IPMN'de ise K-ras mutasyonu söz konusudur. K-ras mutasyonu müsinöz kist adenomlarda \%33 iken; ana kanal ve yan dal IPMN'lerde yaklaşık \%60 bildirilmiştir $(30,31)$. Ayrıca yapılan ölçümlerde müsinöz kistlerde DNA konsantrasyonu yüksek bildirilmiştir. Bir çalışmada müsinöz kist şüphesi olan 100 hastada CEA ve moleküler analiz birlikte yapılmış, müsinöz kistik lezyonları tanımlamada sensitivitesi \%100 saptanmıştır (32). Kist sıvısında genetik incelemeler yapmanın dezavantajı çok pahalı olmalarıdır. Bu nedenle DNA analizinin rutinde yapılması önerilmemektedir. Ancak sitoloji ve CEA ölçümünün müsinöz neoplazi ayrımında yetersiz olduğu ve cerrahi rezeksiyon endikasyonu net olmayan hastalarda kullanılması önerilmektedir.

\section{Endoskopik Ultrasonografi Eşliğinde İnce İğne Aspirasyonu + Firçalama}

EUS-FNA ile yeterli oranda müsin hücresi elde edilememesi üzerine daha fazla müsin hücresi elde etmek için kist sıvısının aspirasyonu gündeme gelmiştir $(13,14)$. Bu yöntemin epitel hücrelerini ve intrasellüler müsini gösterme oranı yüksektir. Bu işlem için özel üretilmiş fırçalar vardır (Echobrush, Cook). Fırçalama için kistin çapı en az 2 cm olmalıdır. İşlem sırasında 19 Gy iğne kullanılması nedeniyle boyun, gövde ve kuyruk yerleşimli kistler tercih edilmektedir. Pankreas başı ve uncinat process'de kullanımı iğne sert olduğu için sinırlıdır. Kist veya mural nodule firça ile 4-6 kez dokunmak yeterlidir, işlem öncesi antibiyotik proflaksisi mutlaka yapılmalıdır. Ĕger kişi antikoagülan almakta ise fırçalama işlemi yapılmamalıdır (14). Bir çalışmada 37 hastada 39 kiste EUS-FNA ve fırça işlemi yapılmıştır (37 kistin çapı $<2 \mathrm{~cm}$ ). Intrasellüler müsin varlığını göstermede tek başına sitolojinin başarısı \%23 iken; sitoloji+ firçalamanın başarısı \%62 saptanmıştır (13).

EUS-FNA işlemine bağlı genel komplikasyonlar \%0.3-2.2 arasındadır. Pankreasın kistik lezyonlarındaki en önemli sorun enfeksiyon riskidir. Tüm EUS işlemleri içinde enfeksiyon \%0-6 oranında görülür. Solid lezyonlarda oran \%0.4-1 iken kistik lezyonlarda ortalama \%3'dür. Anbiyotik proflaksisi yapılamayan olgularda enfeksiyon oranı \%14 rapor edilmiştir. Diğer komplikasyonlar ise, kanama: \%1.3-4, pankreatit: \%0.2-2'dir. Tümör hücresi yayılımı ise sadece 4 vaka (perigastrik, mediasten ve pankreas kuyruğu) bildirilmiştir (33).

\section{Endoskopik Ultrasonografi Eşliğinde Pankreasın Neop- lastik Kistlerinin Tedavisi (Ablasyon Tedavisi)}

$\mathrm{Bu}$ işlem minimal invaziv girişim olup yaşlı ve cerrahi için yüksek riskli hastalarda alternatif tedavi seçeneğidir. Ablasyon amaçlı etil alkol, serum fizyolojik ve kemoteropatik ajanlar kullanılır. Verilen ajanların etkisiyle kist içindeki proteinler presipite olur ve mebranda erime gözlenir. Kullanılan alkolün konsantrasyonu değişmekle birlikte minimal etkin konsantrasyon en az \%40 olmalıdır. Ablasyon öncesi kist içi sıvı tama yakın aspire edilir. Daha sonra yaklaşık kist çapı kadar ablasyon yapicı ajan enjekte edilir. Uniloküler kistler 1-2 seansta, büyük kisitlere ise daha uzun seanslarda ablasyon yapılır. Verilen alkol bir kaç dakika bekledikten sonra geri aspire edilir.

25 hastalık bir çalışmada \%5-80 gibi değişik oranlarda etil alkol kullanılmış ve 23 vakaya 6 ay ile 1 yll sonra cerrahi rezeksiyon işlemi yapılmış. 23 hastanın 8'inde (\%35) tam iyileşme, 2 hastada kist çapında azalma saptanırken; 8 hastada kist çapı stabil kalmış (34). Başka bir çalışmada ise alkol ve serum fizyolojik ile ablasyon tedavisi için 42 hasta randomize edilmiştir. Alkol grubuna 25 hasta, serum fizyolojik grubuna 17 hasta alınmıştır. Kist boyutunda azalma alkol grubunda $\% 42.9$, serum fizyolojik grubunda ise sadece \%11.4 saptanmıştır. Tam ablasyon alkol grubunda 4 hastada görülürken; 


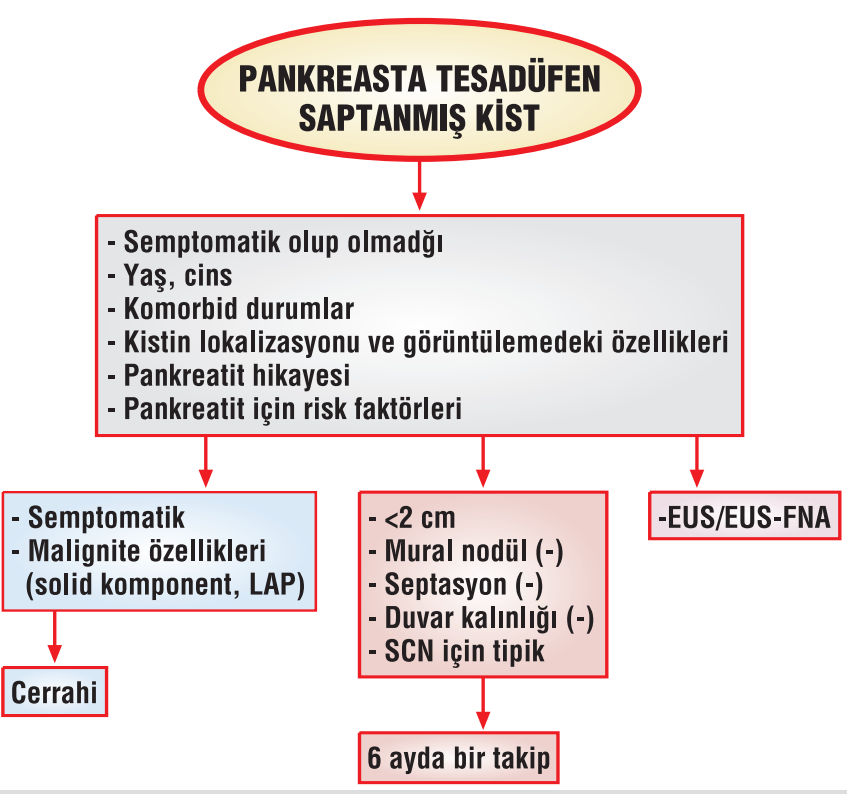

Şekil 2. Pankreasta tesadüfen kist saptanan hastaya yaklaşım

serum fizyolojik grubunda hiç gözlenmemiştir. Pankreasitit ve ağrı gibi komplikasyonlar açısından her iki grup arasında fark saptanmamıştır (35).

Ablasyon tedavisinde kullanılan bir diğer ajan ise kemoterapötiklerdir. 14 hastalık bir çalışmada hastalara önce alkol ile lavaj ve takiben $3 \mathrm{mg} / \mathrm{ml}$ paklitaksel verilmiş. Ortalama kist çapı 14-52 mm ve kullanılan alkol konsatrasyonu \%8899'muş. Alkol verildikten sonra 3-5 dakika beklenmiş. Takiplerde 14 hastanin 11 tanesinde (\%79) tam gerileme, 2 hastada parsiyel gerileme saptanırken 1 hasta ise yanıt alınamamıs. Komplikasyon olarak sadece bir hastada hafif pankreatit (hiperamilazemi, karın ağrısı) gözlenmiş (36).

\section{Pankreasın Neoplastik Kistlerinde Takip Nasıl Olmalı?}

Pankreasta yapılan incelemeler sırasında tesadüfen kist saptanmış ise; kişinin semptomatik olup olmadı̆̆ı, pankreatit öyküsü varlığı, pankreatit için risk faktörleri, yaşı, cinsiyeti, komorbit durumu, kistin lokalizasyonu ve görüntüleme yöntemlerindeki görümüne bakılır. Eğer kişi semtomatik ve kistin malign olabileceğini gösteren özellikler varsa (solid, komponent, kist çevresinde lenf bezi, duvar kalınlığı) direkt cer- rahiye verilir. Kist çapı $2 \mathrm{~cm}$ altında, mural nodul, septasyon ve duvar kalınlığı yok ve görüntüleme yöntemleri seröz kisti düşündürüyorsa 6 ayda bir takip veya EUS yapılır. Bir başka olasılık ta tesadüfen saptanan kistlerde direkt EUS ve EUSFNA yapılmasıdır (7) (Şekil 2).

EUS-FNA sonucu sitopatolojik değerlendirme de müsinöz kist rapor edilirse hasta direkt cerrahiye verilir. Non-müsinöz kist olarak yorumlanan vakalara ya EUS-FNA tekrarlanır ya da 6 aylık aralıklarla radyolojik takibe alınır. Kistin yan dal IPMN, 2 cm altında, mural nodül negatif ve komorbit durumlar varsa hasta yakın takibe alınır. Eğer ana kanal IPMN saptanmış ise kişi cerrahiye verilir (7) (Şekil 3).

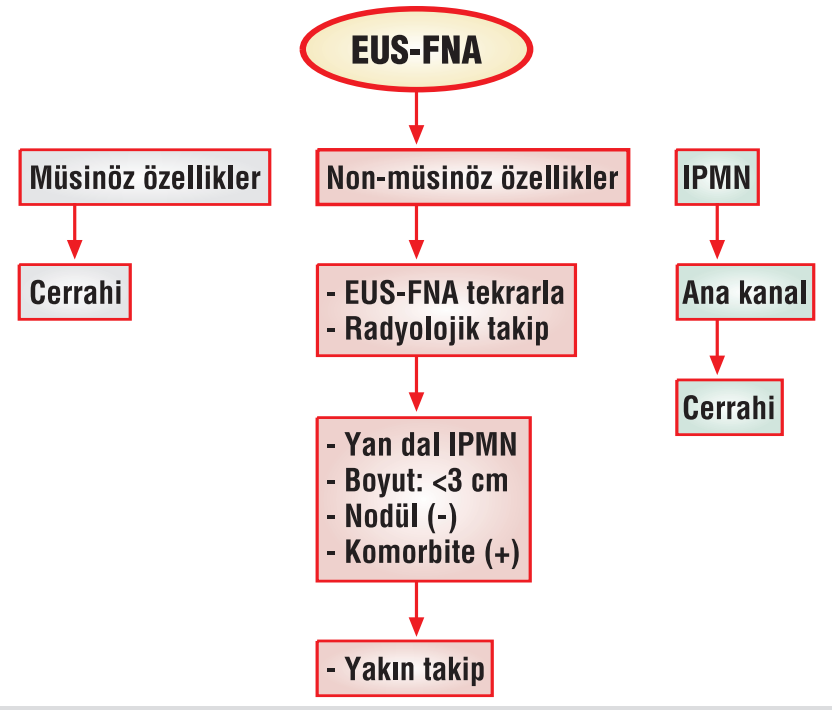

Şekil 3. EUS- FNA sonucuna göre pankreas kistlerinin takip algoritmi

Sonuç olarak günümüzde pankreasın kistik neoplazilerinin tanısı BT, MRI gibi görüntüleme yöntemlerinin yoğun kullanılması nedeniyle giderek artmaktadır. Tek başına EUS ile ancak kistlerin \%50'sinde malign - benign ayrımı yapılabilmektedir. EUS-FNA + kist sıvısının analizi (amilaz, tümör markerlari ve DNA analizi) müsinöz ve malign kistlerin tanısal doğruluğunu artırır. Çok yaşlı ve operasyon için yüksek riskli hastalarda, kistlerin EUS eşliğinde ablasyon tedavisi, etkin ve güvenilir bir yöntem gibi görünmektedir.

\section{KAYNAKLAR}

1. Spinelli KS, Fromwiller TE, Daniel RA, et al Cystic pancreatic neoplasms: observe or operate. Ann Surg 2004; 239: 651-7.

2. Brugge WR, Lauwers GY, Sahani D, et al. Cystic neoplasms of the pancreas. N Engl J Med 2004; 351: 1218-26.

3. Fernandez-del Castillo C, Warshaw AL. Cystic neoplasms of the pancreas. Pancreatology 2001; 1: 641-7.

4. Mulkeen AL, Yoo PS, Cha C. Less common neoplasms of the pancreas World J Gastroenterol 2006; 12: 3180-5.
5. Sakorafas GH, Sarr MG. Cystic neoplasms of the pancreas; what a clinician should know. Cancer Treat Rev 2005; 31: 507-35.

6. Hutchins GF, Draganov PV. Cystic neoplasms of the pancreas: a diagnostic challenge. World J Gastroenterol 2009; 15: 48-54.

7. Fernández-del Castillo C, Targarona J, Thayer SP, et al. Incidental pancreatic cysts: clinicopathological characteristics and comparison with symptomatic patients. Arch Surg 2003; 138: 427-34. 
8. Gorin AD, Sackier JM. Incidental detection of cystic neoplasms of the pancreas. Md Med J 1997; 46: 79-82.

9. Garcea G, Ong SL, Rajesh A, et al. Cystic lesions of the pancreas. A diagnostic and management dilemma. Pancreatology 2008; 8: 236-51.

10. Parra-Herran CE, Garcia MT, Herrera L, Bejarano PA. Cystic lesions of the pancreas: clinical and pathologic review of cases in a five year period. JOP 2010; 11: 358-64.

11. Thomas T, Bebb J, Mannath J, et al. EUS-guided pancreatic cyst brushing: a comparative study in a tertiary referral centre. JOP 2010; 11: 163-9.

12. Al-Haddad M, Gill KR, Raimondo M, et al. Safety and efficacy of cytology brushings versus standard fine-needle aspiration in evaluating cystic pancreatic lesions: a controlled study. Endoscopy 2010; 42: 127-32.

13. Johnson CD, Stephens DH, Charboneau JW, et al. Cystic pancreatic tumors: CT and sonographic assessment. AJR Am J Roentgenol 1988; 151: 1133-8.

14. Koito K, Namieno T, Nagakawa T, et al. Solitary cystic tumor of the pancreas: EUS-pathologic correlation. Gastrointest Endosc 1997; 45: 26876.

15. Curry CA, Eng J, Horton KM, et al. CT of primary cystic pancreatic neoplasms: Can CT be used for patient triage and treatment? AJR Am J Roentgenol 2000; 175: 99-103.

16. Gress F, Gottlieb K, Cummings O, et al. Endoscopic ultrasound characteristics of mucinous cystic neoplasms of the pancreas. Am J Gastroenterol 2000; 95: 961-5.

17. Warshaw AL, Rutledge PL. Cystic tumors mistaken for pancreatic pseudocysts. Ann Surg 1987; 205: 393-8.

18. Kloppel G, Luttges J. WHO-classification 2000: exocrine pancreatic tumors. Verh Dtsch Ges Pathol 2001; 85: 219-28.

19. Mathieu D, Guigui B, Valette PJ, et al. Pancreatic cystic neoplasms. Radiol Clin North Am 1989; 27: 163-76.

20. Minami M, Itai Y, Ohtomo K, et al. Cystic neoplasms of the pancreas: comparison of MR imaging with CT. Radiology 1989; 171: 53-6.

21. Koito K, Namieno T, Ichimura T, et al. Mucin-producing pancreatic tumors: comparison of MR cholangiopancreatography with endoscopic retrograde cholangiopancreatography. Radiology 1998; 208: 231-7.

22. Brugge WR, Lewandrowski K, Lee-Lewandrowski E, et al. Diagnosis of pancreatic cystic neoplasms: A report of the cooperative pancreatic cyst study. Gastroenterology 2004; 126: 1330-6.

23. Al-Haddad M, El Hajj II, Eloubeidi MA. Endoscopic ultrasound for the evaluation of cystic lesions of the pancreas. JOP 2010; 11: 299-309.
24. Khalid A, Brugge W. ACG practice guidelines for the diagnosis and management of neoplastic pancreatic cysts. Am J Gastroenterol 2007; 102: 2339-49.

25. Frossard JL, Amouyal P, Amouyal G, et al. Performance of endosonography-guided fine needle aspiration and biopsy in the diagnosis of pancreatic cystic lesions. Am J Gastroenterol 2003; 98: 1516-24.

26. Attasaranya S, Pais S, LeBlanc J, et al. Endoscopic ultrasound-guided fine needle aspiration and cyst fluid analysis for pancreatic cysts. JOP 2007; 8: 553-63.

27. Bektas M, Lee JH, Guha S, et al. Prevalence of extrapancreatic cysts in patients with cystic neoplasms of the pancreas. American Colloge of Gastroenterology Meeting- San Diago 2009 (poster)

28. Bektas M, Ross WA, Lee JH, et al. EUS-FNA for diagnosis of cystic pancreatic neuroendocrine tumors: an important cause for pancreatic cysts. American Colloge of Gastroenterology Meeting- San Diago 2009 (poster).

29. Sugiyama M, Atomi Y. Extrapancreatic neoplasms occur with unusual frequency in patients with intraductal papillary mucinous tumors of the pancreas. Am J Gastroenterol 1999; 94: 470-3.

30. Berthélemy P, Bouisson M, Escourrou J, et al. Identification of K-ras mutations in pancreatic juice in the early diagnosis of pancreatic cancer. Ann Intern Med 1995; 123: 188-91.

31. Tada M, Teratani T, Komatsu Y, et al. Quantitative analysis of ras gene mutation in pancreatic juice for diagnosis of pancreatic adenocarcinoma. Dig Dis Sci 1998; 43: 15-20.

32. Sawhney M, Devarajan S, O'Farrell R, et al. Comparison of CEA and DNA analysis in 100 consecutive patients with pancreatic cysts. Gastrointest Endosc 2008; 67:AB209

33. Jenssen C, Dietrich CF. Endoscopic ultrasound-guided fine-needle aspiration biopsy and trucut biopsy in gastroenterology - An overview. Best Pract Res Clin Gastroenterol 2009; 23: 743-59.

34. Gan SI, Thompson CC, Lauwers GY, et al. Ethanol lavage of pancreatic cystic lesions: initial pilot study. Gastrointest Endosc 2005; 61: 746-52.

35. Dewitt et al . A prospective, randomized, double blind study of ethanol versus saline lavage of CPT. Gastrointest Endosc 2007; 65: AB106.

36. Oh HC, Seo DW, Lee TY, et al. New treatment for cystic tumors of the pancreas: EUS-guided ethanol lavage with paclitaxel injection. Gastrointest Endosc 2008; 67: 636-42. 